\title{
The importance of evaluating programs of school, family and community partnerships
}

\author{
Joyce L. Epstein \& Steven B. Sheldon
}

Johns Hopkins University - Baltimore (U.S.)

\begin{abstract}
Educators know that "What gets measured gets done." Historically, however, they have avoided evaluating programs and practices of school, family, and community partnerships. They focused, instead, on evaluating other components of school organization (e.g., curriculum, achievement test scores), and weakened programs of family and community engagement. Studies indicate that when school-based partnership teams take time to evaluate their efforts, they demonstrate a seriousness of purpose that leads to more equitable outreach to engage all families in their children's education, and more goal-linked engagement activities that contribute to student success in school. This article presents information on no-cost, low-cost, and costly ways to evaluate the quality and progress of plans and practices of family and community engagement. We discuss the difference between evaluating program implementations and evaluating program results. We identify more than a dozen tools and templates that make it possible for all schools to organize, evaluate, and continually improve their partnership programs.
\end{abstract}

Keywords: Evaluation, school, family, and community partnerships, programs of family and community engagement, simple-tocomplex evaluations.

\section{La importancia de evaluar los programas dirigidos a fomentar la relación entre los centros escolares, las familias y las entidades comunitarias}

\section{RESUMEN}

Los educadores saben que "Lo que se evalúa se hará." A pesar de ello, históricamente han evitado la evaluación de las acciones y programas sobre la relación entre los centros escolares, las familias y la comunidad, centrándose por el contario, en la evaluación de otros componentes de la organización escolar (por ejemplo, el currículo, el rendimiento académico, etc.) y, al hacerlo, han debilitado los programas de relación entre estos tres componentes. Los estudios señalan que cuando en los centros hay grupos de trabajo que evalúan sus actividades, se obtienen resultados que promueven un contexto más equitativo para involucrar a todas las familias en la educación de sus hijos, y un mayor compromiso con las actividades que contribuyen al éxito de los estudiantes. Este artículo presenta información sobre procedimientos sin coste, con bajo coste y alto coste para evaluar la calidad de programas de participación de la familia y la comunidad. Se analiza la diferencia entre evaluar la implementación de programas y evaluar sus resultados. Y se identifican una variedad de formas útiles para que los centros escolares organicen, evalúen y mejoren continuamente sus programas de participación.

Palabras Clave: Evaluación, asociaciones escolares, familiares, y comunitarias, programas de participación familiar y comunitaria, evaluaciones simples a complejas.

\section{Introducción}

Educators are familiar with the saying, "What gets measured gets done." That also applies to programs of school, family, and community partnerships. There is, however, a serious disconnect between recognizing the importance of evaluating programs of family and community engagement and conducting those evaluations.

Hundreds of studies confirm that students do better in school if their parents ${ }^{1}$ and others in the community are interested and involved in their education. Research articles and reports, literature reviews, and meta-analyses of published

\footnotetext{
In this article, the word "parent" refers to anyone who is responsible for a child's learning and development, and who has connections with the school and teachers (e.g., parent, grandparent, foster parent, guardian, or other).
} 
studies indicate that, regardless of family demographics, parents' formal education, language spoken at home, family structure, and other background variables, family involvement helps students improve achievement, attendance, promotion to the next grade, and rates of graduation from high school (Catsambis, 2001; Dearin et al., 2004; Epstein, 2011; Epstein, \& Sheldon, 2006; Fan \& Chen, 2001; Henderson, Mapp, Johnson \& Davies, 2007; Hill \& Tyson, 2009; Jeynes, 2003; 2012; Sheldon, 2019; Simon, 2004; Van Voorhis, Maier, Epstein \& Lloyd, 2013; Wilder, 2014). In particular, goal-linked engagement activities are associated with parents' actions in ways that support student success on the targeted goals.

Further, the principal's support for partnerships is a key component for advancing programs and practices of family and community engagement. Studies confirm that when schools implement well-planned programs and practices with the principals' support, all families can be productively engaged in their children's education at all grade levels (Epstein, Galindo \& Sheldon, 2011; Epstein \& Sheldon, 2016; Sanders \& Harvey, 2002; Sanders \& Sheldon, 2009; Van Voorhis \& Sheldon, 2004). The growing research base has resulted in federal, state, and local policies specifying the need for improving programs of family and community engagement.

Most schools conduct some engagement activities with some parents and community partners. Historically, however, most educators have avoided evaluating the quality and progress of their partnership programs and have not worked systematically to improve their programs over time (Weiss, 1998). Educators have focused mainly on evaluating and improving other components of school organization -especially the curriculum, instructional approaches, and tests and assessments- considered the main components of a good school. Recent studies have shown, however, that family and community engagement is another essential element of good school organization, and contributes to the attainment of other important goals for student learning and development (Bryk et al., 2010, 2015).

With new knowledge and the availability of tested evaluation tools, it is possible for educators to organize, evaluate, and continually improve key components of programs of family and community engagement. These include:

1. Program development (e.g., teamwork, written plans, collegial support for partnerships, links of planned activities to school goals for student success).

2. Program effectiveness (e.g., outreach to families and the community; strategies and technologies to invite, communicate with, and engage all families, especially those who were not previously engaged; outreach to community partners to enrich school programs, students' experiences, and family services).

3. Short term (interim) and long term (ultimate) results of implemented activities for all partners. These include:

a. Results for parents (e.g., communications and questions from parents to educators; responses to invitations and communications from the school; input to school decisions and advocacy actions for their own children's programs; increased and expanded engagement by major racial, ethnic, and socioeconomic groups; increased feelings of confidence to help their children succeed in school; and other "short term" or interim results).

b. Results for schools and teachers (e.g., welcoming climate, school safety, family-friendly atmosphere, attitudes and participation in partnerships by the principal and all teachers; other short term and interim results for schools; transformations for long term improvements to the school organization and (limate) $)^{2}$.

c. Results for students (e.g., academic and nonacademic outcomes - test scores, report card grades, individual or group projects, student work or portfolios, attendance rates, disciplinary referrals, oral presentations; social and emotional development; postsecondary education and career plans).

To evaluate each of the above aspects of programs of family and community engagement, researchers and educators need different measures and appropriate methods of data collection and reporting-some simple and some complex; some low-cost and some costly. Each topic also requires an identified period of time to measure change (e.g., one marking period, one year, fall to spring, two or more years, or other targeted dates).

Researchers and educators ask different questions about the nature and effects of partnership programs and practices. Researchers may use data from one or many locations to ask questions that extend the results beyond the local context: What works? For whom? With what results? How do we know? Will results be replicated in other schools, districts, or communities?

Educators may use data from their own location to ask such questions as: How many and which parents feel welcome at this school? Is each involvement activity in our Action Plan for Partnerships well-designed and well-implemented to engage parents in ways that promote student success? How actively do school and district leaders support our efforts to improve a goallinked partnership program? What ideas do parents, students, and teachers have about improving our program of family and community engagement?

By addressing these and other questions of local interest and importance, each school can learn if it is meeting its goals for effective and equitable family and community engagement. Answers to these questions also should help schools identify next steps to continually improve the school climate, increase the number of families engaged in their children's education at school and at home, and increase student success in school (Epstein et al., 2019; Harvard Family Research Project, 2011). This article discusses topics and tools to help researchers and educators systematically evaluate programs and practices of family and community engagement so that plans, activities, outreach, and, ultimately, results for students improve over time.

\section{Partnership program evaluations in a national network}

At Johns Hopkins University, we invite educators to join with researchers in the National Network of Partnership Schools (NNPS) to use research-based approaches to organize, implement, evaluate, and continually improve goal-linked programs of family and community engagement for student success. By working with hundreds of schools over the past 20 years, we have identified basic structures and processes that

In the U.S., NNPS has identified structures and processes to enable educators in schools, districts, states, and organizations to develop and continually improve their partnership programs (Epstein et al., 2019). In this article, we focus mainly on school-based programs of family and community engagement. 
enable any school to organize an effective partnership program (Epstein et al., 2019). The basics include:

Identify a partnership team. At the school level ${ }^{3}$, a team or committee of teachers, parents, administrators, and others (e.g., counselors, community partners, students at the high school level) has the responsibility for planning, coordinating, and strengthening the school's program of family and community engagement.

Write a plan. The Action Team for Partnerships (ATP) writes an annual One-Year Action Plan for Partnerships, which is the basis for specific evaluations. A four-page action plan identifies specific academic and behavioral goals for student success and for improving the school climate. The template for the plan guides an ATP to outline and schedule the activities for family and community engagement that will be implemented during the school year to help reach the stated goals for student learning and development. (See Appendix A for a sample page of the plan.)

Implement practices using a framework of six types of involvement to engage parents and the community in different ways and places. Studies and fieldwork produced a framework of six types of involvement (Epstein, 1995). The six types are: (1) parenting - help all families establish supportive home environments for children and help the school understand its families; (2) communicatingestablish two-way exchanges using varied technologies about school programs and children's progress; (3) volunteeringrecruit and organize parent assistance at school, home, or other locations, including audiences for student activities; (4) learning at home-provide information and ideas to families about how to help students with homework and other curriculumrelated materials; (5) decision making-have family members serve as representatives and leaders on school committees, and as advocates for their children on school decisions; and (6) collaborating with the community -identify and integrate resources and services from the community to strengthen school programs and enable students to serve the community. The ATP and others work together to design and implement the planned activities on schedule. They take actions to communicate with all students' families, encourage participation, and promote new knowledge and actions for student success.

Evaluate the quality of teamwork and the implementation of activities. The ATP should strive to become and remain a strong voice for effective and equitable partnerships. At monthly team meetings, the ATP should discuss and assess the quality of the engagement activities that were implemented in the past month and plan the activities scheduled in the next month.

This includes checking the One-Year Action Plan for Partnerships to be sure that activities engage all parents in different ways and different places throughout the year-not just at meetings and events at the school building. A well-functioning team examines its plan to ensure that some engagement activities are designed to strengthen a welcoming school climate, whereas other activities are designed to engage families and the community in ways that contribute to student learning and development.

Team members may reflect on questions such as: which families at what grade levels and with what demographics were involved in goal-linked activities to increase students' academic and behavioral success, and which families were missing? Strong teams design and conduct follow-up actions to provide information and resources to families who were unable to attend a school-based event.

\section{Steps in evaluating partnership programs and practices}

Plans for evaluating partnership programs should follow some simple guidelines and logical steps.

Measure implementation first. It is necessary to measure the quality of program implementation before measuring results. Educators need to know if important structures (e.g., team), processes (e.g., written plans, team meetings), and actions (e.g., outreach to all parents, conduct of planned activities) are in place. Teams cannot evaluate the impact of practices they planned, but never implemented. With clear information on which planned activities were implemented and why activities were not implemented, teams can proceed to address questions about participation and results.

Measure quality over time. A moving picture is more informative than a snapshot. Trend data over time on program quality will be more informative than one-time measures. By continually implementing planned activities and reflecting on the quality of the implementation, school teams will be able to discuss how their program and practices may improve from year to year.

Include all partners in evaluations. The concept of "partnership" requires all partners (i.e., teachers, parents, administrators, and others) to serve as members of the ATP and work together to write plans, implement planned activities, and evaluate the quality of each implemented activity. All partners also need to meet together to discuss and assess the quality, progress, and next steps of the school's partnership program at the end of each school year.

\section{Simple-to-complex evaluations}

Districts and schools may assess many aspects of their partnership programs using simple, inexpensive evaluation strategies or by conducting complex and costly studies. All evaluations-simple or complex - should be based on clear questions about the quality, outreach, responses, and results of a program or practice.

To assist researchers and educators, several measures are available for developing and evaluating effective partnership programs. The italicized titles of tools in Table 1 are "built in" to a comprehensive handbook for educators (Epstein et al., 2019).

Plans for partnership begin with Starting Points: An Inventory of Present Practices of School, Family, and Community Partnerships. This instrument helps an ATP take stock of the partnership practices that are already being implemented at a school by at least some teachers as selected grade levels with at least some families and community partners. Presently, the work on partnerships conducted by individual teachers or grade level teams may be unknown to others in the school. Starting Points contributes to decisions about which family and community engagement practices should be continued, improved, or excluded in an initial One-Year Action Plan for Partnerships.

Table 1 shows that even simple evaluations may be useful. For example, sign-in sheets can document how many and who attended an activity. Useful sign-in sheets may include parent's name, full name and grade level of the child (or children), parent's phone, e-mail or social media address for followup communications, and may be paper or electronic rosters of students' names and grade levels. These records collected at activities throughout the school year may reveal whether more and different parents attend meetings and events if the

The most recent UPDATE surveys and resulting annual reports are on the NNPS website, www.partnershipschools.org, in the section Research and Evaluation. 
school improves advertising and invitations, and responds to common requests for extra services such as childcare, dinner, transportation, incentives, and other design features.
Short exit evaluations - usually anonymous-enable parents who attended a workshop to report whether the information was of value to them and offer suggestions for improving future workshops.

Table 1

Simple-to-Complex Evaluations of Programs and Practices

\section{Purpose of Evaluation ${ }^{\mathrm{a}}$ from Simple to Complex}

Assess the status of present partnership practices. Take stock of current activities and identify needed additions

Write a goal-linked plan that outlines and schedules family and community engagement activities

Document and save partnership policies, plans, and other records.

Account for number who attend events or meetings, or number and presence of volunteers; take other tallies of participants (e.g., business partners, home visits conducted, phone calls to and from parents, etc.).

Identify parents and community partners attending an activity who are given information, and whether and how the same information is provided to those who could not attend

Evaluate attendees' immediate reactions to activities and events.

Gather suggestions, questions, ideas from parents about family and community engagement and school programs in two-way school-tohome and home-to school communications

\section{Useful, Tested, Reliable Tools ${ }^{\mathrm{b}}$ and/or Local Designs}

Starting Points: An Inventory of Present Practices of School, Family, and Community Partnerships

One-Year Action Plan for Partnerships

Save computer files in a shareable location (e.g., share folder, Google Docs) or in paper file folders (Local designs)

Sign-in sheets (Local designs)

Electronic record keeping (Local designs, Excel Sheets, Google Docs)

Dissemination and distribution of information and activities (Local designs)

Review documents for clarity, readability (Local designs)

Workshop Evaluations

Exit evaluations (Local designs)

Tear-offs on flyers; exchanges on websites and social media platforms; e-mail; question and suggestion boxes; phone and online surveys (Local designs)

Reflect on and discuss the quality of each engagement activity soon after it is implemented.

Collect the evaluations of activities throughout the year to improve other scheduled engagement activities and to inform the continuing or new goals and activities in the next One-Year Action Plan for Partnerships.

Review and reflect on the quality of teamwork for the Action Team for Partnerships (e.g., membership, organization of team and meetings, communications, leadership, attention to annual plan)

Celebrate and share successes, collect and disseminate excellent activities.

Annual Evaluation of Activities

Annual Review of Team Processes

Site-specific retreats or equivalent meetings

Promising Partnership Practices

District and state collections of best practices (Local designs)

Assess the frequency and prominence of partnership practices at all grade levels in a school; monitor progress in meeting key challenges for the six types of involvement

Measure the quality and progress of essential elements of partnership program development: teamwork, planning, principal support, district support, outreach to all parents, attention to challenges to engage unengaged families, etc.

Site-specific, annual, or periodic surveys, interviews, or focus groups of teachers, parents, and students in elementary, middle, and high schools

Measure of School, Family, and Community Partnerships

Annual UPDATE ${ }^{1}$ survey

1: UPDATE is a member-service of NNPS. See annual reports of UPDATE data at www.partnershipschools.org in the section Research and Evaluation)

See available surveys reported below and the NNPS website, www. partnershipschools.org in the section Publications and Products for Surveys and Summaries (Local designs)

Assess the quality and progress of programs and practices of family and community engagement

Assess effects of partnerships on outreach to and responses by parents, community partners

Assess the effects of family and community involvement on student outcomes (e.g., attendance, behavior, achievement in reading or other subjects, homework completion, credits earned, graduation rates, or other indicators of success in school)
Studies of quality, progress, and results require adequate samples, appropriate measures, and researchers' able to apply advanced statistical methods of analysis. These studies may be conducted by official district, state, or ministry research offices, or under contract with external evaluators.

Note: a) These assessments were conducted by and with schools and districts in the National Network of Partnership Schools (NNPS) to evaluate the quality and progress of their programs and the results of activities for family and community involvement. For a full list of references, see www. partnershipschools.org in the section Research and Evaluation.

b) The italicized tools are included in Epstein, et al., (2019) in print form and on a CD in the book for easy duplication and distribution. Other tools must be locally designed, as noted. 
Studies of results of family and community engagement activities also may be simple and low-cost or complex and costly.

No-cost assessments of results may be based on teachers' observations of student behaviour. For example, teachers may observe that students whose parents attended a workshop on the importance of attendance had fewer absences and more on-time arrivals than before the workshop.

Low-cost assessments of results of a workshop on student attendance may include phone conversations or interviews with a purposive sample or a random sample of parents who attended the workshop or received information on school attendance policies and makeup assignments. Follow up interviews may include questions of if and how parents applied the information from the workshop to discussions and actions at home with their children. Low-cost evaluations of attendance may be conducted at one school using available students' attendance records.

Simple assessments cannot tell, conclusively, if and how parents who attended a workshop or meeting changed or improved their actions at home, or if their children's school attendance, engagement, or achievement changed as a result of the parents' participation at a school activity. Actual results for students of parents' participation at a workshop on the importance of student attendance require systematically-collected data on students' prior attendance, parents' participation, resulting attendance, and other variables of interest.

High cost, rigorous evaluations include pre- and postworkshop data collections on student attendance, or attendee vs. matched non-attendee samples of parents, or other related comparisons. Such data could show if there were initial and resulting differences in the attitudes and actions of parents who did or did not participate in a workshop on student attendance, or in the pre- and postattendance records of students whose parents did or did not participate.

Each evaluation strategy has pros and cons in terms of costs, time, participants, data gathered or ignored, and expertise needed to collect, analyze, interpret, and report the data. Educators and researchers must decide which evaluations will be timely and cost effective for them, and how to use available resources to assess and improve practices of family and community engagement for student success.

\section{Interpreting results of evaluations on partnerships}

There are two major ways to review results for students' academic or behavioral outcomes of evaluations of programs and practices of school, family, and community partnerships. Some studies report the combined effects of school improvement initiatives. Other studies aim to isolate the independent effects of family and community engagement activities or interventions.

Combined Effects of School Improvement Efforts. A researchbased approach to partnership program development recognizes that educators, parents, and community partners share responsibility for students' education and-togethermay boost students' success in school. As noted above, an ATP will write a One-Year Action Plan for Partnerships to identify and schedule family and community engagement activities that promote a welcoming school climate and that contribute to specific academic and behavioral goals for student learning and development (e.g., improve reading or math skills, increase ontime attendance).

For example, if teachers are working with students to improve reading skills, reading attitudes, and reading test scores, the partnership team will select ways to engage families so that they can support children's reading skills and attitudes on one page of the action plan. The team may use tools described in this article to examine the quality of family and community engagement, and will use available measures to monitor progress toward the stated goals for students (e.g., reading records, report cards, and literacy achievement test scores).

With limited time or funds to collect longitudinal data on reading-related outreach activities and parents' responses with their children on reading, an ATP must focus on the combined effects of school and family actions to improve results for students. Evidence of students' higher reading skills and scores and positive attitudes toward reading must be attributed to the efforts of all partners and school initiatives. Lower student reading achievement will signal the need to review and improve the curriculum, instruction, and family and community engagement.

As another example, a One-Year Action Plan for Partnerships may focus on the school goal, "Increase average daily attendance to 96 percent." Activities in the plan may include: positive classroom incentives to encourage all students to attend school regularly; a rewards program of community-business discounts for parents and students for good or improved attendance in each marking period; information for all parents on school attendance policies, how children make up classwork and homework missed on days absent; and the connections of attendance with student achievement. Educators will review official records of average daily attendance, chronic absence, on-time arrival, class cutting, and quarterly changes in attendance rates.

Improved attendance would be attributed to the comprehensive and combined efforts of all partners - teachers, students, parents, and community partners to help students maintain or improve attendance. No change or poorer attendance would require a review of the school's attendance incentives and consequences of absence, and to the information and activities for parents to guide their children to attend school every day and on time.

Many researchers must identify and report combined effects of teachers, policies, and family engagement on student outcomes. Without longitudinal or comparative measures, it is impossible to isolate the independent effects of a school policy, curriculum in a specific subject, family engagement activities, students' motivational forces, and other components of the learning process.

Independent Effects of Partnerships. Most schools and districts do not have funds, time, or staff to conduct studies to isolate the independent effects of programs or practices of family and community engagement. Instead, they may rely on their reflections and observations to gauge how well a family engagement activity was implemented (e.g., using the Annual Evaluation of Activities). Some will find it sufficient to identify the combined effects of school and family activities to know that student learning or behavior is moving in the right direction.

Some educators in well-resourced locations may work with their research and evaluation offices or with external evaluators to isolate the independent effects on students of the partnership program or a specific activity or intervention. Studies of independent effects address difficult questions, such as: does a 
specific family engagement practice contribute measurably to an identified goal for student success (e.g., improve reading scores), over and above the work that teachers do with students in class? Studies of the independent effects of partnerships require wellspecified research models; adequate samples or comparative samples; appropriate longitudinal measures of inputs, throughputs, and/or outcomes; and staff or external researchers to analyze and report the results of the study.

A research model may specify paths of influence shown in Figure 1. This model includes measures of student, family, and school background factors (e.g., parents' education, language at home, socioeconomic status, students' prior achievement test scores), district leaders' actions to support schools' work on partnerships, school-based implementations of partnership practices, parents' responses to outreach, and targeted student outcomes. Figure 1 show that a complete study will account for what districts or education leaders do, what schools do, and what parents do with their children to identify whether and how engagement activities improve results for students. The model may focus on isolating short-term, interim, and/or long-term results of partnership programs and specific activities (Westmoreland, López \& Rosenberg, 2009).
Analyses of independent effects might explore questions such as: After accounting for student background factors and the prior year's family engagement, does leadership on and support for partnerships affect the quality of implementation of schools' partnership programs, including the outreach to more and different families and results for students? Specifically:

- Which paths of influence in Figure 1 affect the number of parents who become involved?

- Does family engagement in goal-linked activities boost students' skills or scores on theoretically-linked outcomes (e.g., reading or attendance) over and above the students' scores on these measures in the prior school year? Holding constant prior scores makes it possible to learn whether there are significant independent effects of family engagement programs or practices on selected outcomes.

Researchers have conducted studies examining all of the paths in Figure 1. Model to Identify Independent Effects for Students of School, Family, and Community Partnerships*

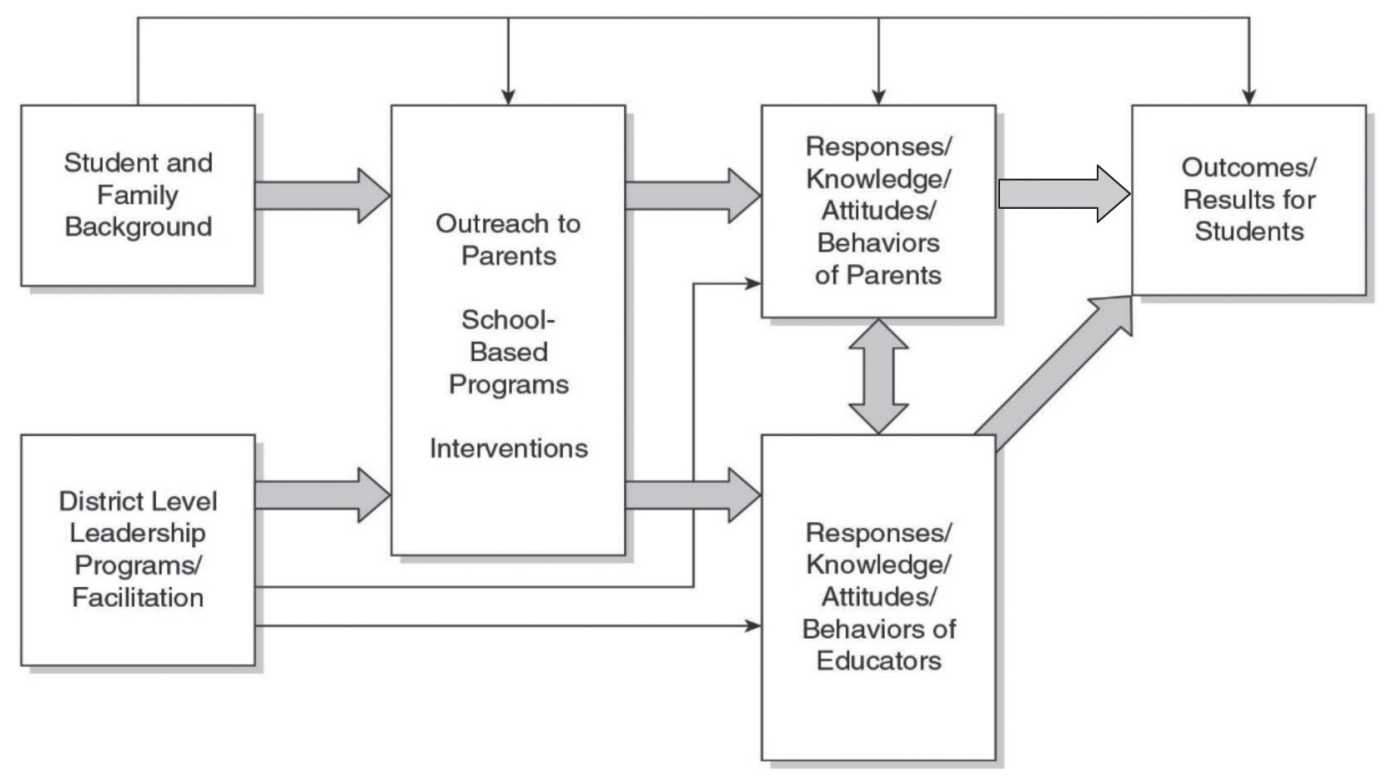

Figure 1. Model to Identify Independent Effects for Students of School, Family, and Community Partnerships

*Assume longitudinal paths that loop and link these variables over time in multi-year measures

Studies of the full model show that, with background characteristics accounted for statistically, partnership programs that are evaluated are higher in quality. High quality programs reach out to more and different parents, and have more parents who are "good partners" with the school (Sheldon, 2005). Schools with greater numbers of engaged parents report higher rates of students' average daily attendance (Epstein \& Sheldon, 2016; Sheldon, 2009; Sheldon \& Van Voorhis, 2004). In short, outreach to engage more families is likely to affect how and how many parents support their children's work and success in school, including encouraging more students to attend school on a regular basis. Other studies have identified significant paths of influence in the model (Sheldon, 2003, 2005, 2007).

\section{Using research-based approaches to improve partnership programs}

In the U.S. and in other locations, school leaders are required to use research-based approaches to improve school programs and practices, including family and community involvement (U.S. Department of Education, 2016). That means that educators select evidence-based tools and strategies to guide their plans and actions of program development, based on reports of positive effects across published studies. Educators are not expected to replicate complex and costly research studies in their own schools. Rather, educators may use proven approaches with confidence that they will have similar positive results as in 
prior studies. Often, however, district and school leaders want to know if the selected research-based approaches are effective in their own locations. To address this question, educators may conduct local evaluations-simple to complex-according to their budgets and staff.

For example, longitudinal studies of Teachers Involve Parents in Schoolwork (TIPS) interactive homework in math in the elementary grades and language arts and science in the middle grades organized treatment and control groups, statistically controlled for students' prior test scores, parents' education, amount of homework completed, and other background variables (Van Voorhis, 2011). These studies showed that parents of students in TIPS classes worked more often with their children on interactive homework than did parents of students in the control groups. Also, TIPS parents and students had more positive attitudes and emotions about math homework, and students had higher math achievement test scores than in nonTIPS classes.

A well-funded, quasi-experimental, longitudinal research study was the researcher's responsibility. Researchers will continue to test TIPS approaches in other subjects and grade levels to create a knowledge base on interactive homework. Now, educators can use the studies of interactive homework as the research base for their decisions about whether to implement TIPS.

To learn how well TIPS works for their own teachers, students, and families, educators can use "built-in evaluations" in the TIPS process to monitor students' homework completion, accuracy, and responses from parents (Epstein, 2017; Epstein \& Van Voorhis, 2019). These "evaluations" include the number of TIPS assignments returned, as well as feedback provided by the homework partner about the child's understanding and enjoyment of the assignment on the assignments themselves. With an eye to the combined effects of teachers' class lessons, "regular" homework, and TIPS interactive homework, teachers and principals can monitor results for students using class tests, report card grades, and achievement test scores to learn whether TIPS contributes to the success of students in their classrooms.

Inquiry Processes. Educators can and should conduct systematic inquiries on how well their school is progressing in implementing a strong and sustainable program of school, family, and community partnerships. This includes periodic reflections and discussions on how well the partnership team is working together, and how well each planned activity is implemented.

There are several labels for reflective processes including developing a culture of inquiry; conducting a plan-do-study-act (PDSA) cycle of inquiry; or following a Results Oriented Cycle of Inquiry (ROCI) to plan, act, assess, reflect on, and adjust practices (Bryk, Gomez, Grunow \& LeMahieu, 2015; Mac Iver et al., 2018; Partners in School Innovation, 2016). In all cases, inquiry processes aim to help educators discuss how to make continuous improvements to reach important goals (Park, Hironaka, Carver \& Nordstrom, 2013).

In work on family and community engagement, schoolbased partnership teams need to reflect on and discuss how well each activity was implemented; whether each activity reached the intended participants; and whether and how the team might improve the design, implementation, and outreach if the activity were conducted in the future. In NNPS, we use a simple tool, Annual Evaluation of Activities, which enables team members to reflect on the features of each activity after it is implemented. (See Appendix B for a sample page of the evaluation template.)

\section{Surveys on school, family, and community partnerships}

There are many kinds of simple-to-complex surveys that focus on aspects of family and community engagement, including (1) comprehensive surveys that the authors conduct to understand the organization of school-based partnership programs; (2) surveys for individual parents, teachers, and students to provide opinions and requests about family and community engagement; and (3) local surveys that educators may develop on their own.

Comprehensive Surveys of Program Quality and Development. Because schools' ATPs struggle to conduct comprehensive evaluations of their partnership programs, the authors conduct annual surveys for and with the schools, districts, states, and organizations that are members of the NNPS at Johns Hopkins University. This member-service has three purposes:

(1) Annual evaluations, called UPDATE surveys, help schools monitor the strengths and weaknesses of their plans, processes, and practices, and identify areas for improvement;

(2) Annual evaluations enable schools to demonstrate a seriousness of purpose in conducting and continually improving programs of partnership; and

(3) Annual data from a large number of schools in diverse communities are used by the research team to improve the knowledge base on essential elements for partnership programs that engage all families in ways that support student success in school.

The annual UPDATE surveys include reliable scales and repeated measures of essential elements in developing effective programs of family and community engagement. These surveys include scales and measures of the nature and quality of program leadership; teamwork; written plans; implementation; outreach to engage previously uninvolved parents; funding, collegial support from principals, district leaders, and others; evaluation; and networking. ${ }^{4}$

General Surveys of Parent, Teacher, and Student Attitudes. Some schools, districts, and states conduct surveys to assess the attitudes and experiences of key partners in students' education-parents, teachers, administrators, and the students themselves. Surveys for individual parents, teachers, and students in the elementary and middle grades, and in high schools explore the perspectives, attitudes, experiences, of these partners in education (Epstein \& Salinas, 1993; Epstein, Connor-Tadros \& Salinas, 1993; Sheldon and Epstein 2007).

The surveys for parents, for example, include reliable measures of school outreach to involve families; parents' attitudes about the school; present family involvement; parents' requests for engagement; parents' beliefs about their responsibilities and skills for engagement (role construction and efficacy); social networks and connections with other parents and other adults; and family demographics. Similarly, surveys of students and teachers include several reliable scales to gauge respondents views on present practices of family engagement, attitudes about the schools, improvements needed on partnerships, and related topics.

Also see other surveys of parents, including the Harvard Graduate School of Education and Survey Monkey forms (2014) and the National Association for the Education of Young Children (NAEYC, 2016). These surveys of parents may be tailored in content and length to support local conditions and constraints. The surveys include measures of parents' support for and valuing of education at home; parental engagement; school climate and feelings of welcome; parent views of their responsibilities for engagement, and confidence about guiding their child's education. 
Educators who aim to conduct surveys of parents, teachers, or students must consider the resources needed to print, mail, present electronically, track return rates, process data, conduct statistical analyses, and report results. Teacher and student surveys tend to have high return rates as they are typically completed at school or in class. Parent surveys tend to have low response rates, often under $30 \%$. Although general surveys may provide some useful feedback, costs may outweigh the benefits.

Some less costly strategies (e.g., focus groups, forums, and interviews with purposive samples of parents and community members) may provide useful information on school climate and needed improvements in family and community engagement. Most importantly, plans and actions to strengthen school programs and practices are needed to improve results from one general survey to the next. There is no point in conducting general surveys of parents if there are no engagement activities and means to improve programs from one year to the next.

Create Local Questionnaires. School teams and other education leaders may create their own surveys of parents, students, and/or teachers to gather ideas for improvements or to evaluate specific programs and practices of family and community engagement. These may range in complexity from short exit evaluations of reactions to parent workshops or school events; to questionnaires at the start of a new school year to identify volunteers' interests, talents, and time available to assist teachers, administrators, and students; to formal school climate surveys of parent satisfaction with the school's programs and communications.

There are a few basic steps for developing clear and useful local questionnaires, as shown in Table 2.

Table 2.

Basic Steps for Designing Local Surveys of Parents ${ }^{a}$

1. Determine what you want to know

2. Focus the questionnaire on a specific topic

3. Keep surveys short and anonymous

4. If multiple-choice answers are offered, make each response category clear and unique. Do not combine two or more ideas in one question. You will not know which part of the question was addressed

5. Avoid "yes/no" answers. These tell whether respondents like or dislike something, but not how much. Or, they tell whether respondents have "ever" or "never" done something, but not how often. "No" is clear, but "yes" refers to undefined quantities and qualities. Instead, use response categories that identify frequency or intensity.

6. If open-ended questions are included, provide sufficient space for written responses.

7. Make surveys easy for all parents to read and provide translations as needed.

8. Consider having surveys completed at the school site (e.g., at a popular event for parents) to maximize the response rate. Or, consider electronic forms that can be easily accessed from home and quickly completed.

9. Consider incentives such as rewards for classrooms with high returns of parent surveys. Do not connect survey returns to students' grades in any way

10. Explain how you will use the information

11. Give enough time for parents to complete the questionnaires

12. Provide a summary of results

Note: ${ }^{a}$ Educators may take the same steps in developing local surveys for teachers and students.

Report Results. The results of evaluations of partnership programs, activities, and general surveys of parents' satisfaction with schools should be shared with those who participated in the surveys, interviews, or focus groups, and with education leaders and other interested parties. Results may be shared with families via a school newsletter, website, e-mail or social media, local media (e.g., radio, cable TV, foreign language outlets), and in other forms. Summaries of data on the status and progress of a school's partnership program should be presented to the School Improvement Team, Parent Teacher Association (PTA) or Parent Teacher Organization (PTO), school board, and other interested groups.

\section{Make time/take time to evaluate partnership programs}

Studies show that when teams take time to evaluate, their schools are more likely to improve the overall quality of their partnership programs. When school teams and education leaders take their work on school, family, and community partnerships seriously enough to conduct evaluations, they are more likely to use the results to improve their plans and activities.

We conclude that evaluation is an essential element of any partnership program that aims to improve from year to year. Without assessing progress to identify strengths and weaknesses of programs, there is no way to know where actions are needed to sustain good work or improve weaknesses.

Evaluations of family and community engagement should not be conducted to label programs "good" or "bad." Useful evaluations clarify program goals, identify strengths and weaknesses, and help partnership teams plan improvements. By evaluating all parts of a partnership program and continually improving the design, outreach, and results of plans and practices from year to year, all families and the public will see that the school is a "partnership place" where all partners share in their children's education.

\section{References}

Bryk, A. S., Sebring, P. B., Allensworth, E., Luppescu, S., \& Easton, J. Q. (2010). Organizing schools for improvement: Lessons from Chicago. Chicago, IL: University of Chicago Press.

Bryk, A. S., Gomez, L., Grunow, A., \& LeMahieu, P. (2015). Learning to improve: How America's schools can get better at getting better. Cambridge, MA: Harvard Education Publishing.

Catsambis, S. (2001). Expanding the knowledge of parental involvement in children's secondary education: Connections with high school seniors' academic success. Social Psychology of Education, 5, 149-177.

Dearing, E., McCartney, K., Weiss, H. B., Kreider, H., \& Simpkins, S. (2004). The promotive effects of family educational involvement for low-income children's literacy. Journal of School Psychology, 42, 445-460.

Epstein, J. L. (1995). School/family/community partnerships: Caring for the children we share. Phi Delta Kappan, 76, 701-712.

Epstein, J. L. (2011). School, Family, and Community Partnerships: Preparing Educators and Improving Schools, Second Edition. Boulder CO: Westview.

Epstein, J. L. (2017). Manual for teachers: TIPS interactive homework (elementary and middle grades). Baltimore: Center on School, Family, and Community Partnerships at Johns Hopkins University.

Epstein, J. L.et al. (2019). School, family, and community partnerships: Your handbook for action, fourth edition. Thousand Oaks, CA: Corwin.

Epstein, J. L., \& Salinas, K. C. (1993). School and family partnerships: Questionnaires for teachers and parents in elementary and middle grades. Baltimore: Center on School, Family, and Community Partnerships at Johns Hopkins University. 
Epstein, J. L., \& Sheldon, S. B. (2006). Moving forward: Ideas for research on school, family, and community partnerships." In C. G. Conrad and R. Serlin (Eds.), SAGE handbook for research in education: Engaging ideas and enriching inquiry, (pp. 117137). Thousand Oaks, CA: Sage.

Epstein, J. L., \& Sheldon, S. B. (2016). Necessary but not sufficient: The role of policy for advancing programs of school, family, and community partnerships. Russell Sage Foundation Journal of the Social Sciences, 2(5), 202-219.

Epstein, J. L., \& Sheldon, S. B. (2019). Evaluate programs of partnership: Critical considerations. In J. L. Epstein et al. School, family, and community partnerships: Your handbook for action, fourth edition. (pp. 323-359). Thousand Oaks, CA: Corwin.

Epstein, J. L., \& Van Voorhis, F. L. (2019). How to implement Teachers Involve Parents in Schoolwork (TIPS) processes. In J. L. Epstein et al. School, family, and community partnerships: Your handbook for action, fourth edition. (pp. 283-322). Thousand Oaks, CA: Corwin.

Epstein, J. L., Connors-Tadros, L., \& Salinas, K. C. (1993). High school and family partnerships: Questionnaires for teachers, parents, and students. Baltimore: Center on School, Family, and Community Partnerships at Johns Hopkins University.

Epstein, J. L., Galindo, C., \& Sheldon, S. B. (2011). Levels of leadership: Effects of district and school leaders on the quality of school programs of family and community involvement. Educational Administration Quarterly 47, 462-495.

Fan, X., \& Chen, M. (2001). Parental involvement and students' academic achievement: A meta-analysis. Educational Psychology Review, 13, 1-21.

Harvard Family Research Project (2011). Evaluating family engagement strategies: Addressing measurement challenges (Webinar). https://uww.adobeconnect.com/p7apep6zaw2/?launcher=false \&fcsContent=true\&pbMode=normal.

Harvard Graduate School of Education. (2014). Parent survey for K-12 schools. See www.surveymonkey.com/mp/harvardeducation-surveys/.

Henderson, A. T., Mapp, K. L., Johnson, V. R., \& Davies, D. (2007). Beyond the bake sale: The essential guide to family-school partnerships. New York: The New Press.

Hill, N. E., \& Tyson, D. F. (2009). Parental involvement in middle school: A meta-analytic assessment of the strategies that promote achievement. Developmental Psychology, 45, 740-763.

Jeynes, W. H. (2003). A meta-analysis: The effects of parental involvement on minority children's academic achievement. Education and Urban Society, 35, 202-218.

Jeynes, W. H. (2012). A meta-analysis of the efficacy of different types of parental involvement programs for urban students. Urban Education, 47, 706-742.

Mac Iver, M., Sheldon, S., Epstein, J., Rice, E., Mac Iver, D., \& Simmons, A. (2018). Engaging families in the high school transition: Initial findings from a continuous improvement initiative. School Community Journal, 28, 37-66.

NAEYC (2016). Self assessment family survey. Washington, D. C.: National Association for the Education of Young Children. See https://ase.tufts.edu/epcs/documents/infoFamilySurvey. pdf.

Park, S., Hironaka, S., Carver, P., \& Nordstrum, L. (2013). Continuous improvement in education. Stanford, CA: Carnegie Foundation for the Advancement of Teaching.
Partners in School Innovation (2016) Results oriented cycle of inquiry (ROCI). See https://www.partnersinschools.org/ services/results-oriented-cycles-of-inquiry-roci/.

Sanders, M. G., \& Harvey, A. (2002). Beyond the school walls: A case study of principal leadership for school-community collaboration. Teachers College Record, 104, 1345-1368.

Sanders, M. G., \& Sheldon, S. B. (2009). A principal's guide to school, family, and community partnerships. Thousand Oaks, CA: Corwin Press.

Sheldon, S. B. (2003). Linking school-family-community partnerships in urban elementary schools to student achievement on state tests. The Urban Review, 35, 149-165.

Sheldon, S. B. (2005). Testing a structural equation model of partnership program implementation and parent involvement. Elementary School Journal, 106, 171-187.

Sheldon, S. B. (2007). Improving student attendance with school, family, and community partnerships. Journal of Educational Research, 100, 267-275.

Sheldon, S. B. (2009). Using evaluation to prove and improve the quality of partnership programmes in schools. In R. Deslandes (Ed.), International perspectives on contexts, communities and evaluated innovative practices: Family-school-community partnerships (pp. 126-142). New York, NY: Routledge.

Sheldon, S. B. (2019). Improving student outcomes with school, family, and community partnerships: A research review. In J. L., Epstein et al. School, family, and community partnerships: Your handbook for action, fourth edition (pp. 43-62). Thousand Oaks, CA: Corwin.

Sheldon, S. B., \& Epstein, J. L. (2007). Family and community involvement in the elementary and middle grades: Student survey and parent survey. Baltimore: Center on School, Family, and Community Partnerships, Johns Hopkins University.

Sheldon, S. B., \& Van Voorhis, F. L. (2004). Partnership programs in U.S. schools: Their development and relationship to family involvement outcomes. School Effectiveness and School Improvement, 15, 125-148.

Simon, B. S. (2004). High school outreach and family involvement. Social Psychology of Education, 7, 185-209.

U. S. Department of Education (2016). Using evidence to strengthen educational investments.https://www2.ed.gov/policy/elsec/leg lessa/guidanceuseseinvestment.pdf

Van Voorhis, F. L. (2011). Adding families to the homework equation: A longitudinal study of mathematics achievement. Education and Urban Society, 43, 313-338.

Van Voorhis, F. L., \& Sheldon, S. B. (2004). Principals' roles in the development of U.S. programs of school, family, and community partnerships. International Journal of Educational Research, 41, 55-70.

Van Voorhis, F. L., Maier, M. F., Epstein, J. L., \& Lloyd, C. M. (2013). The impact of family involvement on the education of children ages 3-8: A focus on literacy and math achievement outcomes and social-emotional skills. New York: MDRC.

Westmoreland, H., López, M. E., \& Rosenberg, H. (2009). How to develop a logic model for districtwide family engagement strategies. Cambridge, MA: Harvard Family Research Project.

Weiss, C. H. (1998). Have we learned anything new about the use of evaluation? American Journal of Evaluation, 19, 21-33.

Wilder, S. (2014). Effects of parental involvement on academic achievement: a meta-synthesis. Educational Review, 66, 377397. 


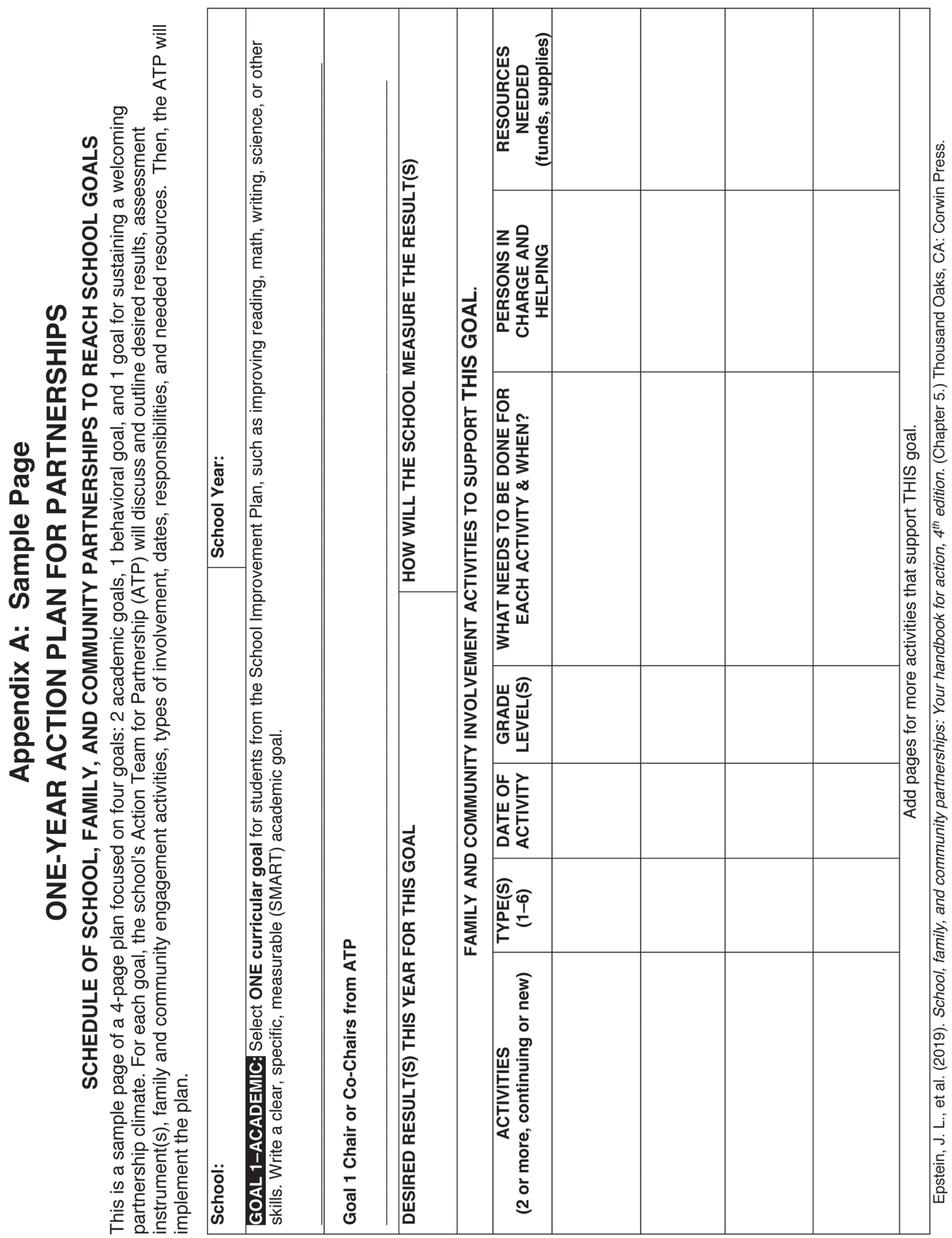




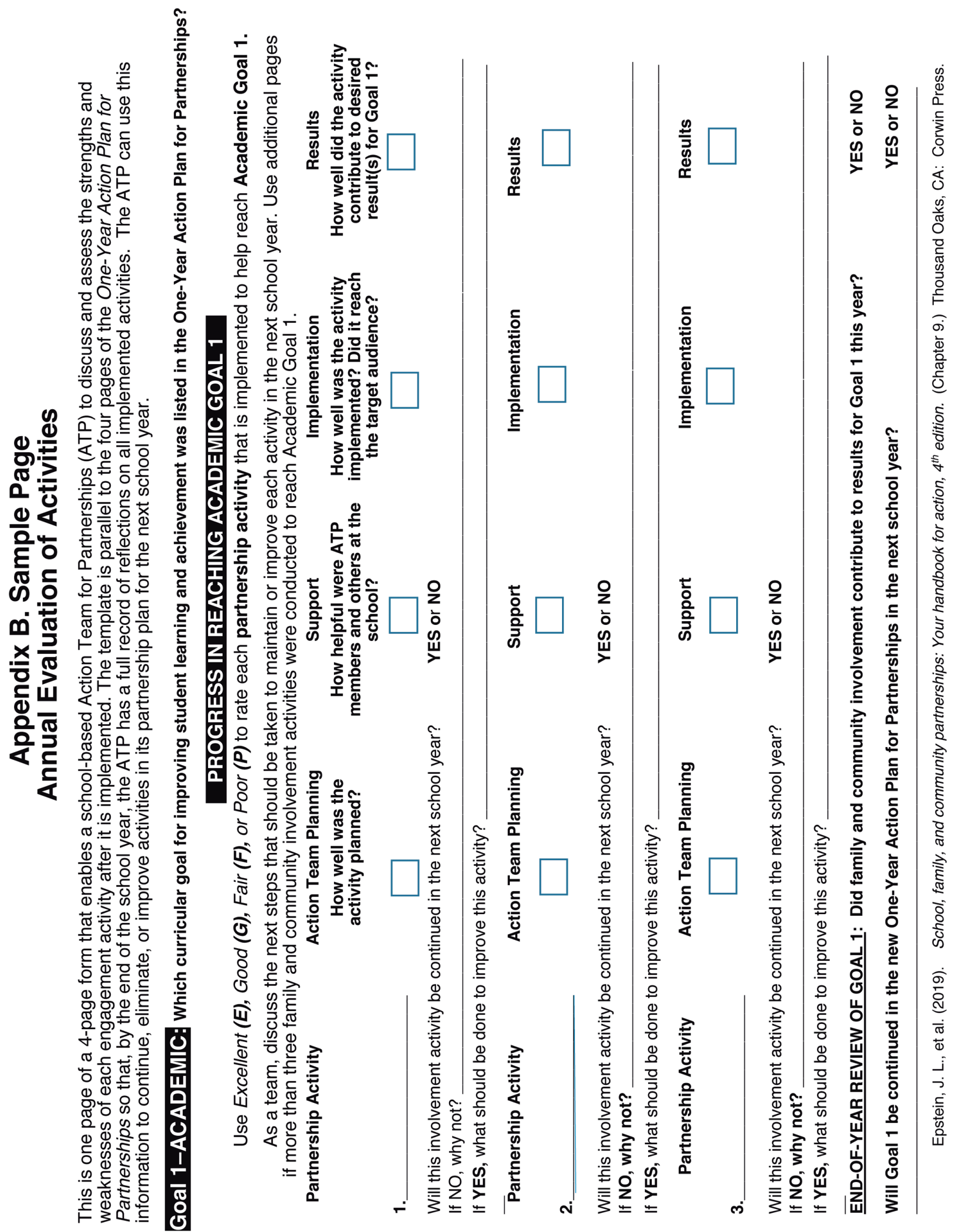


